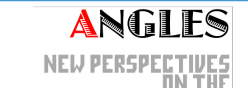

ANELOPHONE WORLD

\section{Angles}

New Perspectives on the Anglophone World

$5 \mid 2017$

The Cultures and Politics of Leisure

\title{
We Are the One: Subcultural Politics and Leisure in Early San Francisco Punk
}

\section{Michael Stewart Foley}

\section{(2) OpenEdition}

1 Journals

Electronic version

URL: https://journals.openedition.org/angles/1133

DOI: 10.4000/angles.1133

ISSN: 2274-2042

\section{Publisher}

Société des Anglicistes de l'Enseignement Supérieur

\section{Electronic reference}

Michael Stewart Foley, "We Are the One: Subcultural Politics and Leisure in Early San Francisco Punk", Angles [Online], 5 | 2017, Online since 01 November 2017, connection on 08 June 2022. URL: http:// journals.openedition.org/angles/1133 ; DOI: https://doi.org/10.4000/angles.1133

This text was automatically generated on 8 June 2022

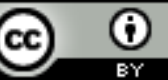

Angles est mise à disposition selon les termes de la Licence Creative Commons Attribution 4.0 International. 


\title{
We Are the One: Subcultural Politics and Leisure in Early San Francisco Punk
}

\author{
Michael Stewart Foley
}

\section{AUTHOR'S NOTE}

The author is grateful for the valuable research assistance of Marijn Rombouts, who provided critical help at various stages in advancing this paper toward publication.

1 In 1977, the year that punk became a global sensation, Penelope Houston, lead singer of the Avengers, wrote the lyrics to what became the singular anthem of the San Francisco punk scene. In the first verse to "We Are the One," she captured both the power and exhilaration of the city's youthful rebel culture:

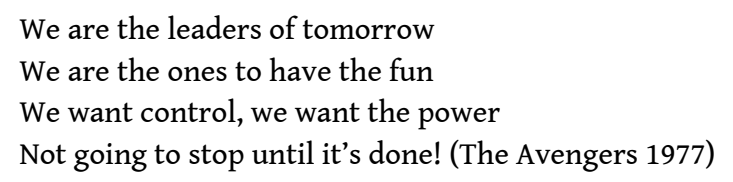

2 With its aggressive drum attack and slashing guitar riffs, "We Are the One" seemed capable of sparking not only frenzied pogo dancing, but also a rush to the barricades. As soon as punks at the Mabuhay Gardens, the city's counterpart to New York's CBGB's, heard the opening guitar lines, they broke into shouting these lyrics which cathartically gave voice and physical expression to themes of both leisure and politics. Although the song could, in fact, be seen as a tongue-in-cheek comment on political anthems - shouting everything they were not (messiahs, fascists, capitalists, communists, etc.) and saying, cryptically, that they are "the one" - it is representative of the power punks believed they possessed to tear down the old (whether in San Francisco or the wider United States) and build the new - all while having "the fun." (The Avengers 1977) 
San Francisco's enduring association with the counterculture of the 1960s has obscured its history as one of the United States' essential 1970s punk cities. Instead, New York, Los Angeles, and Washington get all the attention as epicenters of American punk. But San Francisco was home to the most deliberately political punk scene in the country, if not the world. At the same time, as the lyrics to "We Are the One" suggest, San Francisco punks - like punks everywhere - experienced their scene as deliriously fun. This is not to say that punks thought about their lives in more traditional, bourgeois terms of leisure; they would have rejected, in knee-jerk fashion, the very idea of mainstream leisure as a salve for the soul, created and commodified to help alienated Americans swallow the mind-killing experience of the workaday world. Still, if slamdancing to thunderous music was not the same as taking a cruise or lounging at the country club, there is no denying the fun and even escapism that punk offered.

4 This mix of politics and fun is not, of course, unique to San Francisco punk. Subcultures scholars have long written about participants choosing the "subterranean world of play" in response to the predictability and boredom of mainstream life, as a way to assert "creative, skillful, self-determining action." (Young 877) Specifically writing about the meaning of punk, Dick Hebdige famously described its style as "an oblique challenge to hegemony." (Hebdige 17) But others, such as Joseph Heath and Andrew Potter, have argued that sub-cultural leisure actually undermines political change: "Having fun is not subversive, and it doesn't undermine any system" they write. In fact, Heath and Potter suggest, fun makes organizing social movements and effecting political change more difficult (Heath and Potter 2004). ${ }^{1}$

5 This article argues for a more nuanced understanding of the intersection of politics and fun in punk. In San Francisco, punk politics went beyond oblique challenges to hegemony and, rather, confronted neoliberal elites and the forces of inequality and injustice directly. At the same time, punks acted deliberately to not only intertwine fun and politics, but to make fun and play vehicles for political struggle, if not revolution. At least in this one major American city, punk was equal parts political engagement and diversion, equally confrontational and escapist. Social movement theorists who have investigated the role of emotion in political mobilization would not be surprised by this; it makes sense that emotion - particularly anger and joy - would mobilize punks politically. More importantly, the leisure and fun elements contributed to the building of a prefigurative community as a micro-model of what punks hoped could be achieved on a larger scale. In that way, fun and politics contributed to a fundamentally utopian vision in a subculture marked not by nihilism - as punk is so often cast - but by possibility. ${ }^{2}$

6 Historical context on a national, state, and urban level is essential in order to understand the power and potential of San Francisco's punk scene. For example, by the late 1970s, few would deny that the United States was in decline. American confidence suffered not only from defeat in Vietnam, political corruption and paranoia as a result of Watergate and related scandals of government spying on its own citizens, and challenges from two major oil crises and a series of environmental disasters; most important, the national economy that had, for decades, sustained the great expansion of the American middle class, finally saw a major correction. Although historians now see that period of mid-century economic power and liberal progress as "the great exception," the vast majority of Americans suffering from the worst economic downturn since the Great Depression grew exasperated at the nation's inability to 
return to greatness - to a level of prosperity to which they had grown accustomed and perceived as the norm (Cowie 2016). When President Jimmy Carter gave an honest appraisal of the national malaise, and pointed to the country's "crisis of confidence," the electorate voted him out of office (Mattson 2009). A variety of factors reinforced this sense of national decline in what one historian has called "a decade of nightmares" - a seeming epidemic of child abductions, serial killings, cult activity, drug abuse underscored for many an American culture that had gone over the edge (Jenkins 2006). Meanwhile, anxieties about the supposed bedrock of American society - the nuclear family, faced with rising divorce rates and unsupervised latch-key children, seemingly in decline - paralleled anxieties about the nation as a whole (Zaretsky 2007). It was no surprise that, in the mid-1970s, Americans eagerly embraced the signature line of the Academy Award-winning film Network: "I'm mad as hell, and I'm not going to take it anymore!"3

7 American punks were mad as hell, too, but unlike their mainstream counterparts in the electorate, they felt not betrayed by the government - in which they had had little faith, anyway - so much as by the counterculture and New Left, both of which seemed to promise radical change when punks were kids. Instead, punks found that those cultural and political radicals had, by the late 1970s, given up the revolution before it could be won and instead, echoing Christopher Lasch's critique of the American "culture of narcissism," retreated to their hot tubs and new age lifestyles (Foley 19, 33).

In San Francisco, where the counterculture and New Left once flourished, that abdication of political engagement resulted, many punks thought, in a city being rapidly gifted to real estate developers who quickly marginalized - with help from a landlord mayor and aggressive police enforcement - the minority, immigrant and poor populations that were central to the city's identity. It was a common pattern. As American cities deindustrialized and lost much of their tax base, policy makers sought to make up the shortfall by bringing in new investments to gentrify old neighborhoods. The resulting dispossession of San Francisco from long-term residents has turned out to be the dominant theme of the city's history in the last forty years, as it has in other cities, but in San Francisco, punks led the resistance to what the band The Mutants called "The New Dark Ages."

Since punk functioned in San Francisco more as a rebel culture than as a social movement - though the terms "movement" and "scene" are today used by punk veterans almost interchangeably - it produced no clear manifesto. Rather, punks engaged politics at multiple levels, standing on the one hand in joyful defiance of mainstream culture while, on the other hand, deliberately engaging specific political concerns of the nation, state, and city. That engagement manifested itself in multiple, interwoven ways - through utopian critiques of the mainstream culture, by engaging specific national issues of the moment, and primarily by claiming and fighting for particular urban spaces in San Francisco. These political stands were central not only to much of the music produced by the city's bands, but they were at the heart of what the community considered both its work and its play: imagining and enacting a better city and country.

10 Among core punk writers and thinkers, the power of punk lay in its potential to build a community that would stand in opposition to mainstream American culture and that would challenge the complacent to join them. For V. Vale, the editor of Search \& Destroy, San Francisco's most influential zine, punk gave everyone in the scene an opportunity 
to make art, to be creative, but the key was to ensure that whatever one made it had to be "against the status quo (which is always changing)." In Search \& Destroy, Vale tried to provide an enduring document of "an entire social revolution, as it was happening." (Vale 2013) In a typical Search \& Destroy interview, Danny Furious, drummer for The Avengers, criticized mainstream politics as well as the indifference among young people. "I think that putting total conviction into what we're doing is the statement that's the politics," he told Vale. "Getting up and smacking some of those assholes that have just come [to a show] to boogie in the face - [because] it's not just entertainment!!!" ("The Avengers" 4)

11 By the end of 1979, punks were already worried about being co-opted and found themselves repeating the need to resist mainstream values. In response to music corporations courting some San Francisco punk bands, Brad Lapin, the editor of Damage (a kind of successor to Search \& Destroy) reasserted what he saw, still, as punks' essential mission: "What we should want and what we should make clear by our attitudes, our songs, our music, our venues, our publications, our lives," Lapin wrote, "is that this scene represents one thing if nothing else: A COMPLETE, A TOTAL REJECTION OF THE MINDLESSNESS OF CONFORMITY AND MASS CULTURE." (Lapin 30) As we will see, there was a utopian quality to this call for building an alternative society in which Americans (not only punks) could live their lives on their own terms. But their vision did not look only inward; indeed, punks consistently critiqued the mainstream and especially the mainstream media for failing to understand the essence of punk. The media did not want to "accept punk as what it is or what it should be," Tony Kinman of the Dils, perhaps the most obviously ideological band in San Francisco, told Search \& Destroy. "They wanna accept it as another little entertainment - they'd like a punk cartoon show on Saturday morning!," Kinman said, when, in fact, he argued, punk should be seen "as a force, like to WRECK THINGS! TO TRANSFORM!" ("Avengers \& Dils " 12-3) No doubt, some punks would have perceived the earnest anger of Lapin and Kinman as amusing or perhaps as punks taking themselves too seriously, but they were representative of the way most punks saw themselves resisting straight society.

One side of V. Vale's call for everyone to do something creative emphasized conducting and sharing research, almost as amateur pathologists examining a diseased American body politic. For example, they took seriously the re-intensifying Cold War and explicitly tied their concerns about foreign policy to questions of class and inequality in the city. Defeat and deceit in Vietnam did a lot to shape their cynicism and produce their critique of American society, with Cold War references running through their music, zines, fashion and art. Johnny Genocide (née Hugh Patterson) of the band No Alternative remembers a kind of punk salon, with punks meeting up nearly every night and the best informed among them sharing what they knew. Punks like Peter Urban, manager of the Dils', and others served as a "clearinghouse" for information on global political events. As a result, songs like "The Amerikan in Me," by the Avengers, resonated with punks precisely because so few trusted the federal government. "Ask not what you can do for your country, but what your country's been doing to you," Penelope Houston sang in the chorus. Similarly, bands and zines emphasized workingclass Americans being sacrificed by the military even before draft registration returned in 1980, while others anticipated the next Vietnam War and future use of the neutron bomb - both of which, some punks argued, could be used in a class war to wipe out the poor (Vale 2013; Patterson 2014). ${ }^{5}$ 
13 At other times, punks organized around specific issues of injustice, even if somewhat distant from San Francisco. They held benefit concerts for an enormous range of political issues - on behalf of striking Kentucky miners, striking railway workers, wrongfully imprisoned Black Panthers, and Dessie Woods (a woman who had been convicted of killing her rapist with his own gun). They brought "Rock Against Racism" concerts to San Francisco, organized a festival for Amnesty International, and played anti-draft rallies, protested against nuclear power, and played "Rock Against Work" on two consecutive International Labor Days. At the Mabuhay Gardens, punks enlisted gay city supervisor Harvey Milk to MC a benefit for a campaign to defeat a California ballot initiative that would ban homosexuals from teaching in the public schools, and, closer to home, raised money to keep open the Gay Community Center at 330 Grove Street.

In these ways, punk's independent researchers fulfilled the role of teachers while other punks were students. Michael Reid, a Londoner who moved to San Francisco in 1979 and organized shows at the Mabuhay Gardens said that rank and file audiences "were not that politically knowledgeable" and that "they were dependent on what they read in these fanzines." Band interviews in zines and statements from the stage often introduced readers to important issues. "If a kid wants to go see The Zeros or The Dils," Reid remarked, "he's going to go to that gig and he's going to learn who [Black Panther] Geronimo Pratt is, and that's how they got a lot of their political education, because you're not going to get that from the mainstream news or Channel 5 because they're going to call that person a criminal." In effect, artists replaced traditional news sources (Reid 2013).

For some punks, it seemed appropriate that punk politics overran punk escapism. Peter Urban, who managed both The Dils and The Zeros used to introduce The Dils at shows by saying: "It's 1977 . There is no time for fun! Here's the Dils!" When Urban was interviewed with Malcolm McLaren for Slash, and the interviewers asked him to sum up, he said "take less drugs, wear more clothes, and overthrow the bourgeoisie". Even Urban admits today that he was very dour, particularly in his public persona, and so were The Dils. "We were tired of people saying things they didn't mean," he recalled years later. "This is the world we were born into, and we recognize it. Our eyes are open. It looks like this, and it smells like shit and especially we're sick of your lies... There's lots of shit in the world, and we've got to talk about it." (Urban 2013)

Most important, San Francisco punks focused their protest on the forces they saw destroying their city: real estate developers, the police, and a City Hall that emboldened both. They fought police in sidewalk defenses as tenants were evicted from residential hotels - such as the International Hotel in Manilatown - and other low-income housing to make way for the gentrification wrecking ball. When former city supervisor and cop, Dan White, was convicted only of manslaughter, despite confessing to the murders of Mayor George Moscone and supervisor Harvey Milk, punks led the riot at City Hall, pelting the building with bricks and stones, and setting fire to a dozen police cars (an image of which is used as the cover to Dead Kennedys' first LP). Steven Brown of Tuxedomoon earnestly read testimony from the trial when the band would play its cover of the Rolling Stones' "1 $19^{\text {th }}$ Nervous Breakdown," and the band later headlined one of several benefit concerts held for the riot defense fund. When Moscone's successor, Dianne Feinstein, ran for election in her own right, in 1979, she was challenged by Dead Kennedys lead singer, Jello Biafra, who focused his critique on Feinstein being a landlord, cozy with real estate interests and promised, instead, 
legalized squatting, rent control, and for neighborhoods to hold periodic yes and no confidence votes on the police who patrolled them. ${ }^{6}$

Benefit concerts and a punk prankster mayoral challenge are perhaps more obviously fun than confrontations with police in the streets (though more than a couple of people have described the White Night riot as "fun") but the point is that the zines, song lyrics, gigs - both routine performances and benefit concerts - as well as participation in street protests demonstrated a significant degree of political engagement within a scene that could still be considered, because it had music and performance at its center, a zone of leisure. Of course, this is true for most subcultures - from skateboarding to parkour, northern soul to hip-hop, much of the attraction to a subcultural life lies in the fun, the diversion, the escape from mass society. In late-1970s San Francisco, disentangling the fun from the work of punk, political or otherwise, was impossible. As Penelope Houston later described it, punk leisure was not like bourgeois leisure. "In America, when most people think of leisure, they think of monied leisure," Houston argues. "We had our unstructured days and varying levels of drive." Playing in bands, writing songs, and going to other bands' shows "was kind of our job - but it wasn't work. It was fun." The research culture and emphasis on creativity encouraged punks to pursue their interests, to turn them into avocations if not occupations, in ways that could be both politically intentional and creatively exhilarating. In this way, San Francisco is a model subculture, one in which, as Dick Hebdige argued in 1983, “'politics' and 'pleasure,' crime and resistance, transgression and carnival are meshed and confounded." Ruby Ray, who shot photographs for Search \& Destroy and became one of the scene's most prominent artists, said that even as punks were having so much fun, they still felt like they were doing something important, something historic. It was so exciting, she said, that she could get her work published so quickly and that everyone influenced each other stylistically, aesthetically, politically - sharing "the stuff that was cool." Ray's artistic experimentation showed diverse artistic influences ranging from Russian constructivism, Dadaism, existentialism, to revolutionary Maoist magazines found in Chinatown - all art forms that circulated in the thrilling salon culture of the scene (Dick 1988; Ray 2014).

One way in which punk politics and punk fun were entwined could be seen in an affinity for mischief. Just as Biafra ran for mayor as a prank - as the rascal antagonist of the sitting mayor - Dead Kennedys especially made their name as a band known for promoting mischief. In "Stealing People's Mail," a song on the band's first LP, the narrators in the song sound like a group of joyriding teens, but with a more menacing edge. It is an example of what Biafra called "creative crime." The song's narrators ride around on a Friday night, swiping everything from mailboxes, filling grocery bags with money, wedding gifts, tax returns, and, tellingly, checks written to politicians by realtors. The impression is that they are terrorizing everyone, that the public thinks they are crazy, yet when the narrators "read your letters," they wind up "rolling on the floor," laughing (Dead Kennedys 1980). The band's penchant for mischief reached legendary levels when it played the Bay Area Music Awards (the "Bammies") in 1980. When the band began playing its single, "California Über Alles," some in the crowd cheered, but soon the band changed gears. They dropped the black raincoats they had been wearing to reveal that each was wearing a white shirt with an ' $S$ ' painted on it; their black neckties turned the ' $\mathrm{S}$ ' into dollar signs as they began playing "Pull My Strings," a song, written just for the occasion, about the kind of artists sitting in the audience: rock and rollers prepared to sell their souls to record executives in exchange 
for fame and fortune (Foley: 101-3). As an exercise in political mischief, it rivaled the Yippies bringing trading on the New York Stock Exchange to a halt by dropping dollar bills all over the trading floor.

19 The combination of fun and political purpose both grew out of and reinforced a utopian ethos not usually associated with punk. If punk is typically seen as nihilist, San Francisco punks expressed and enacted ideals that were, in fact, idealistic and emphasized possibility. They did not have a set program nor did they produce, à la the Port Huron Statement, an agenda for their generation, but the scene created space for what cultural studies scholar Lauren Berlant calls an "intimate public," bound by a shared affect to a notion that punks were part of something bigger than themselves. ${ }^{7}$ "It was beautiful and poetic and wonderful and dreamy - in the surrealistic sense of dreamy - it was all of those things," Brad Lapin said years later. "But ultimately it was great fun. It was so much fun." Most important for Lapin and many others, punks created an environment "in which anything and everything is possible, creatively and politically." (Lapin 2014) In short, San Francisco punks engaged politics within a context that was fun, and had fun within a context that was fundamentally political.

The musical performances at the center of San Francisco's punk rebel culture most obviously generated this affective, utopian experience. "Everything we do is a glimpse of possibilities," Will Shatter of Negative Trend (and later Flipper), told Search \& Destroy. "What we do on stage isn't an act. It's real life. The point is to break all the rules and limits. When people leave after seeing us I hope it's that much harder for them to go back to their job or class." ("Negative Trend" 1978) Punks gathered, as theater scholar Jill Dolan has suggested in a different context, to see and hear bands, "hoping, perhaps, for moments of transformation that might let them reconsider and change the world outside." That desire to be "part of the intense present" of a throbbing, pulsating, sweaty crowd at the Mabuhay Gardens or the Deaf Club, offered the audience "if not expressly political then usefully emotional, expressions of what utopia might feel like." Dolan calls these lashes of experience that performance provides the "utopian performative." In making her case, Dolan finds Roland Schaer's definition of utopia most compelling: "Utopia, one might say, is the measure of how far a society can retreat from itself when it wants to feign what it would like to become." It is the other side of what the Israeli anarchist and Straightedge punk Jonathan Pollak has described as "the need to extract oneself from society" being "fueled by the desire to see and live in a different reality." As Dolan notes, "to enact an ideal future, a culture has to move farther and farther from the real into a kind of performative." (Dolan 2001) In this way, punk in San Francisco functioned prefiguratively, much as Sixties social movements had. That is, the scene embodied and provided a model, on a small scale, of what the broader society could or should become. ${ }^{8}$

One key to the public intimacy and prefigurative politics of San Francisco punk was the deployment of black humor in their music, art, and repartee. Even with the occasionally serious outburst on the part of a Peter Urban or Tony Kinman, the experience of the vast majority of punks was defined by both serious political engagement and enjoyment; as part of both, black humor - a kind of warped, sarcastic, off-beat humor - became central to the San Francisco punk experience. Vale of Search $\&$ Destroy was (and still is) the most outspoken proponent of black humor as essential to punk, and not just in San Francisco. "Without black humor," Vale later remarked, "all is lost because people start taking themselves too seriously and believing the hype about 
themselves" as politically or culturally potent. Black humor, by that calculation, was about maintaining a detachment and a certain modesty. The Dead Kennedys, the most prominent band to come out of San Francisco punk - as a punk version of the Yippies - were especially deft at pointing out the absurdity of various political issues via black humor and pranks. Jello Biafra, the band's political mastermind and onetime mayoral candidate, noted in a later interview that "historically, the 'Merry Prankster' has had a lot more to look forward to than the humorless politico who sits around moaning about the "struggle." (Vale 2013; Biafra 2013).

For punks living in San Francisco, even in a time of economic precariousness for the nation and the city, a low-cost lifestyle provided a degree of freedom that made participation in politics and leisure possible. As social movement theorist Alberto Melucci might characterize it, punks functioned like many "submerged networks," in which "experiments in life are carried on, new experiences created, and collective identities forged in everyday life." (Melucci 208) But such experiments are difficult to carry out if one works forty hours a week. "In order to have any kind of youth rebellion," Vale has noted, "you have to have some free time and a meeting place." Punks led the kind of lives that required little money. "It cost only 15 cents to take a bus and just $\$ 25$ to buy a guitar," Vale recalled years later. "There were Xerox machines available for copying, one could easily get on the guest list for shows that cost only $\$ 3$ to begin with, people had rent parties where bands played to raise money to pay the rent, or just lived in cheap SRO hotels in the tenderloin." As it was, Vale's rent was only $\$ 37.50$ a month, and he covered that and all of his other expenses by working two sixhour shifts at City Lights Bookstore each week. Penelope Houston agreed: "We shared flats (about $\$ 225$ for a 3 bedroom flat at 1926 Folsom Street) and ate Top Ramen (ten for a dollar), and had friends who worked at Just Desserts Bakery who gave us endless amounts of pastries (leftovers, or by theft, unpaid gift certificates)... People gave us free studio time." That meant punks had the time, almost every day, to plot their rebellion at their leisure. ${ }^{9}$

It's surprising how, in explaining their unstructured days, so many of San Francisco punks will now talk about how affordable they found the city to be, as if it was not victimized by the deep and prolonged recession of the 1970s - when, by any objective measure, it was. But as Tuxedomoon bass player Peter Principle has remarked, San Francisco was full of "large Victorian rambling structures" which had "gone out of fashion" in the 1950s and 1960s when city dwellers moved to the suburbs or preferred high rises. As a result, even as the elderly were being cleared out of residential hotels to make way for condominium conversions, punks could double, triple, and quadruple up in sprawling flats like the ones where Principle, Houston, and Vale lived with others. At times, a whole house functioned as a kind of punk commune where people lived, created, performed, and recorded. ${ }^{10}$

Punks partly embraced life on the margins as a fun alternative to straight American life, of course, and many lived in much more unconventional sites than old Victorian homes. Many younger punks, including a number of runaways, called The Broadway Hotel, a run-down old welfare hotel, their home in the early years of San Francisco punk. The hotel was located close to Polk Street, where many of them gathered during the day, and they could walk through the tunnel down Broadway to the Mabuhay Gardens, too. Further downtown, most of the band called The Mutants lived in a loft above the Fun Terminal arcade on $1^{\text {st }}$ Street, near the bus station. It was an enormous 
space, big enough to host parties - rent parties were a regular occurrence - that could accommodate nearly everyone who went to shows. ${ }^{11}$ Similarly, Joe Rees, the videographer and driving force behind Target Video (which shot concert videos of nearly every band that played the city's punk clubs) rented most of an industrial building on South Van Ness. Inside, he built a studio and performance space (which frequently functioned as a party space), sublet another floor to Damage magazine, while he and others from Target and Damage built mini-apartments there, too. Later, a large number of punks squatted at "the Vats," the old Hamm's Brewery, using the actual vats as individual dwellings, as well as at the abandoned Polytechnic High School and the vacant Hotel Owners Laundry Company.

These living arrangements sprang, of course, from punk's Do-It-Yourself ethos, which also drove the establishment of venues and other creative spaces that aimed to circumvent the grip of commercial capitalism. Whereas a venue like the Mabuhay Gardens functioned in many ways like a mainstream business, even as it catered to punks (many of whom the promoter Dirk Dirksen let in for free), punks themselves started alternative venues in community centers, a club for the deaf, a Mexican restaurant, a bakery, and any number of other seemingly random places all over the city. Most notably, a group of young punks who thought that both bands and the audience were getting gouged at the Mabuhay formed an organization called New Youth with the primary aim of raising money for a punk performance and recording venue, its own kind of community center (the organization did not raise enough money, but it channeled its funds to various benefit concerts and into building a national directory of DIY venues, radio shows, and record labels) ("New Youth is Everybody" 1979).

As scholars of other subcultural spaces have found, the carving out of such spaces which to outsiders would seem to be purely escapist - are fundamental to building a culture of resistance. They may have been hollows of refuge within a larger society that punks perceived as repressive, but they were sites where love, friendship, and solidarity were built, too. ${ }^{12}$ As Cindy Katz has argued, "young people's growth and development depends upon environments that provide stimulation, allow autonomy, offer possibilities for exploration, and promote independent learning and peer group socializing." (Katz 1998: 141) The geography of punk in San Francisco made such growth and development possible in the spaces where punks lived and went to shows, but also in countless other places - in broadcast radio studios, independent record labels, and television.

Radio, especially, staked a claim for punk in the Bay Area's airwaves and helped hold together the intimate public of punk in northern California. It started in 1976 with a Friday night (Saturday morning) shift from midnight to 2.00 a.m. on KSAN, with DJs Howie Klein and Chris Knabb spinning the latest punk records from the US and UK on a show they first called The Outcastes and, later, The Heretics. When new management took over KSAN and changed its format to all country music, KUSF, the station based at the University of San Francisco, with an incredible 30,000 watts of broadcast power, filled the gap and slowly expanded its punk and new wave programming. Suddenly, the information on bands, gigs, venues, exhibits and punks themselves - also available in the many zines and fliers produced all over the city - was being distributed via radio, directly to punks' bedrooms every day. As one punk DJ later said, reflecting on radio's role in the scene, "it was an incredible time!" (Sullivan 2015) 

but most of all, as with zines, radio opened up possibilities for punks to participate. It is not insignificant that many of the most prominent punk radio voices belonged to women. "The best of punk rock, to me, is that it offered space to anyone who felt different," Denise Sullivan, who DJ'd at KUSF, later remembered. "Free space to just be who you were." Sullivan came to KUSF in 1979, when the city's punk scene was already two years old. "To be welcomed in, to be given opportunities, these tools - like a radio station to operate with a very powerful signal and no limits to speak of - that's, I mean, when is that ever going to happen?" Similarly, Ruth Schwartz, who worked at KUSF as well as on KPFA's "Maximum Rock N'Roll" show, among others, recalls that "independence" was the "driving value" behind the scene, but also there existed a sense that one could mix fun and revolution. The city's punk radio shows, Schwartz said, aimed "first and foremost" to "protest the entertainment industry," but also, more generally, provided a place where one could be "independent from the media, right wing politics, mundane politics, bad art... whatever, you fill in the blank." At the same time, "a lot of people were there because it was loud, nasty rock and roll music that really spoke volumes to them and irritated other people." (Schwartz 2015) ${ }^{13}$

As with the larger scene, the fun and politics of punk radio were inseparable. "The fun aspect for me was very much doing it myself, doing what I want to do," says Sullivan. "That's what it opened the door to." For young women, who grew up in the 1960s and 1970s, with resistance to women's liberation still widespread, finding their way to a place where they could determine for themselves what they wanted to do amounted to a fundamentally political act. "Being a DJ, that was wild fun," Sullivan recalls. "Writing for fan-zines: fun. Going to clubs every single night of the week, fun: So I was engaged in my life." From punk she and others "somehow got this directive of "go out and do what you're interested in."' (Sullivan 2015)

By the end of the decade, San Francisco punks had built an impressive infrastructure of places to live and places to play, all of which served as both prefigurative retreats from established systems of oppression and as staging areas for rebellion. The two editions of the Western Front Festival, held all over the Bay Area, epitomized the culmination of the community's capacity to join leisure and politics. In 1979, Dirk Dirksen of the Mabuhay Gardens and Robert Hanrahan of the Deaf Club came up with the idea to showcase the energy of the Bay Area punk scene on a large scale. The first year this resulted in a ten-day festival with over 60 concerts spread out over the City at "their" venues like the Mab, The Deaf Club, the Geary Theatre and the Savoy Tivoli. When the clubs closed at 2:00 a.m., punks gathered at the Target Video loft for after parties. Target also documented "all phases of the festival" on video and screened excerpts during the late-night parties. Between gigs, bands played live at KUSF and on Maximum Rock n'Roll, while Damage produced a special issue that functioned as a Western Front program. ${ }^{14}$

In 1980, bands played at even more venues and the festival expanded to beyond playing only music to the visual arts as well. In addition to the Mab and the Savoy, Club Generic, Tool \& Die, the I-Beam, $10^{\text {th }}$ Street Hall, Berkeley Square, the Keystone bars in Berkeley and Palo Alto, as well as the venerated hall The old Waldorf hosted shows. And instead of printing only 5,000 special issues, Damage printed 25,000 copies for the 1980 festival (“Western Front: Not so Quiet..." 1980). In a city in which concert promoter Bill Graham possessed almost monopoly power, the Western Front festivals 
marked a grassroots punk uprising. Damage later described Western Front irreverently as "Nine nights and days of music, film, video, poster art, performance art, dance, new work, nuclear war, drinking, losing, winning, having fun, being bored, and shrinking brainpans." (Mr. Me 1980a) But Deaf Club promoter Robert Hanrahan argued for the festival as a declaration of independence. "What the Western Front and the Deaf Club and the Geary and Testing Ground and The Pit and the Roosevelt and the Mabuhay, ad infinitum, have proven," Hanrahan wrote, "is that rock'n'roll is no longer dependent on the moguls, the monster promoters, the moneybags and their pretenders, hirelings and sycophants. The more venues and promotions that fly by the seat of their pants, the less this music will be vulnerable to those who could try to dominate it." (Hanrahan 1980)

Even at the dawn of neoliberal urban policy, as real estate developers, corporations, and their friends in city government began the process of dispossessing the city from its long term residents, punks not only kept their art out of the hands of commercial capitalists but they claimed back parts of the city for themselves. These were mostly capitalist- and conformist-free zones. They established their own venues, made their own music, planted flags with their radio shows and record labels, films and festivals, all documented by their own photographers and cameramen and women. In short, they had built their own small-scale model of a society that they hoped could be achieved nationally.

The Port Huron Statement produced by Students for a Democratic Society in 1962 famously declared that New Leftists would "replace power rooted in possession, privilege, or circumstance" with "power and uniqueness rooted in love, reflectiveness, reason, and creativity." Although San Francisco punks did not reference the Port Huron Statement at all a decade and a half later, that line pretty well sums up the utopian quality of the city's punk community. It may not have been an organized social movement, but punks resisted and fought injustice perpetrated by landlords, developers, City Hall, and the police, not only in lyrics, but in the streets. To borrow from former SDS president Paul Potter, they "named the System[s]" responsible for the marginalization of so many citizens (and not just punks). They engaged with political issues both local and national, from homelessness and gay rights to the miner's strike to the return of draft registration. At the same time, they built a community from the ground up that devoted itself creativity, solidarity, and fun.

Plenty of punks had, perhaps, too much fun, and there were no small number of drug casualties, but that did not mean that they were unaware of political stakes and the long odds of overcoming the forces of repression. "We live in a highly repressive society which is getting worse instead of better," one punk wrote in CREEP in 1980. "We may well live to see full-blown fascism in our time. We live on poisoned food and drink contaminated water. Atomic particles threaten to totally distort our gene pool [...] But we are dancing on the bloody, smoldering mess, dancing with our damaged bodies and souls. We are laughing. We are alive. We are indestructible..." (Kolb 22) That measure of fatalism was common, even as punks tried to create a prefigurative community, even if it would not last. "For the people I hung out with at the Mabuhay, it was like we're gonna make this ours, have our last minute, have fun," Flipper's Bruce Loose told Damage. "It felt like this is it, not that the bomb was going to be dropped, but that corporations were going to turn everybody into mindless robots, so this was out last attempt, last strike at freedom, last chance to express yourself." (Mr. Me 1980b) That 
pairing of total commitment to resistance, even in the face of overwhelming odds against forces far more powerful, somehow added up to a kind of halcyon experience for many young people in the Bay Area. "We were living in our own utopia, without even realizing it," Search \& Destroy's V. Vale recalled years later. It was a utopia where fun and revolution could not be disentangled (Vale 2013). It is an object lesson for scholars who study punk scenes and, more generally, music and politics. For if the fun of punk became, effectively, a discursive tool in San Francisco, used by punks with purpose and in specific circumstances, to effect political ends, it follows that the fun central to other music and art scenes must have possessed the same political potency.

\section{BIBLIOGRAPHY}

\section{Primary Sources}

\section{Music}

The Avengers. “We Are the One." 45 RPM single, Dangerhouse Records SFD-400, 1977. Lyrics reproduced at: http://www.penelope.net/we.html

Dead Kennedys. “Stealing People's Mail." On Fresh Fruit for Rotting Vegetables, LP, Cherry Red Records, B Red 10, 1980.

\section{Oral History Interviews}

Biafra, Jello. Interview with Michael Stewart Foley. Personal interview. Oakland, CA, 24 Sep 2013. Klein, Howie. Interview with Michael Stewart Foley. Personal interview. Los Angeles, CA, 7 Jan 2015.

Lapin, Brad. Interview with Michael Stewart Foley. Personal interview. Atlanta, GA, 14 Apr 2014 Patterson, Hugh. Interview with Michael Stewart Foley. Personal interview. San Francisco, CA, 13 Jan 2014.

Ray, Ruby. Interview with Michael Stewart Foley. Personal interview. San Francisco, CA, 10 Jan 2014.

Reid, Michael. Interview with Michael Stewart Foley. Personal interview. San Francisco, CA, 30 May 2013.

Reininger, Blaine, and Peter Principle. Interview with Michael Stewart Foley. Personal interview. The Hague, Netherlands, 23 November 2016.

Schwartz, Ruth. Interview with Michael Stewart Foley. Personal interview. Sacramento, CA, 22 Sep 2015.

Sullivan, Denise. Interview with Michael Stewart Foley. Personal interview. San Francisco, CA, 23 Sep 2015. 
Urban, Peter. Interview with Michael Stewart Foley. Personal interview. San Francisco, CA, 1 Jun 2013.

Vale, V. Interview with Michael Stewart Foley. Personal interview. San Francisco, 12 January 2013.

\section{Zine Articles}

“The Avengers." Search \& Destroy, No. 3: 4.

“Avengers \& Dils." Search \& Destroy, 6: 12-13.

Centerfold. Damage, No. 4, Jan., 1980: 22-24.

“Contents." Damage, Western Front Festival Edition, Oct. 1979: 5.

Coyote, Ginger. “Local Newz SF.” Damage, No. 1, July ,1979: 29.

Eddie K. “The 1980 Draft Registration.” Damage, No. 10, November 1980: 31.

Happy Geek. “San Francisco.” New York Rocker, No. 20, July, 1979: 38.

Hanrahan, Robert. “A message to Howie Klein.” Damage, No. 5, 1980: 4.

“Local Venues." Damage, Western Front Festival Edition, Oct., 1979: 13, 16.

“Negative Trend." Search \& Destroy, No. 6, 1978: 7.

“New Youth is Everybody.” Damage, No. 1, July, 1979: 30.

“Register Now, Die Later.” CREEP, \#4, 1980: cover.

“San Francisco Summer 1979." Slash, vol. 2, \#9, Oct. 1979: 12.

“Target Video.” Damage, Western Front Festival Edition, Oct., 1979: 12.

“Western Front: Not So Quiet on the Western Front." Damage, No. 9 (September/October), 1980: 29.

Kolb, Terry. "First Impressions of a Scene." CREEP, No. 2, 1979: 22.

Lapin, Brad. "End of the year editorial message.” Damage, No. 4 January, 1980: 30.

McCarthee, Mickee. “Violence: use \& abuse.” CREEP, \#2, 1979: 9.

McCarthy, Mickey. "No Apologies.” CREEP, No. 1, 1979: 3-4, 14.

Mr. Me. “Western Front: Vital Statistics.” Damage, No. 10, September 1980a: 8.

Mr. Me. “Flipper rules ok?” Damage, No. 7 July 1980b: 25.

“Resist the Draft: Refuse to Register!" Ripper, \#8: 5.

“The Western Front.” Damage, No. 4 Jan. 1980: 22-24.

“What Will Happen if You do Not Register for the Draft?” Ripper, \#8: 8.

\section{Secondary Sources}

Berlant, Lauren. The Female Complaint: The Unfinished Business of Sentimentality in American Culture. Durham: Duke UP, 2008.

Boulware, Jack, and Silke Tudor. Gimme Something Better: The Profound, Progressive and Occasionally Pointless History of Bay Area Punk. New York: Penguin, 2009. 
Breines, Winifred. Community Organization in the New Left, 1962-1968: The Great Refusal. Piscataway, NJ: Rutgers UP, 1989.

Brigit, Richard, and Heinz Hermann Kruger. "Ravers' Paradise? German Youth Cultures in the 1990s." in Tracey Skelton and Gill Valentine (eds.), Cool Places: Geographies of Youth Culture. London: Routledge, 1998. 161-74.

Corbisier, Isabelle. Music for Vagabonds: The Tuxedomoon Chronicles. Self-published, 2008.

Cowie, Jefferson. The Great Exception: The New Deal and the Limits of American Politics. Princeton: Princeton UP, 2016.

Dolan, Jill. "Performance, Utopia and the 'Utopian Performative'." Theatre Journal 53 (2001): 457-60.

Foley, Michael Stewart. Dead Kennedy's Fresh Fruit for Rotting Vegetables. New York: Bloomsbury, 2015.

Goodwin, Jeff, James M. Jasper, and Francesca Polletta (eds). Passionate Politics: Emotions and Social Movements. Chicago: U. of Chicago P., 2001.

Gould, Deborah B. Moving Politics: Emotion and ACT UP's Fight Against AIDS. Chicago: Chicago UP, 2009.

Heath, Joseph, and Andrew Potter. Nation of Rebels: Why Counterculture Became Consumer Culture. New York: Harper Business, 2004.

Hebdige, Dick. Subcultures: The Meaning of Style. Oxford: Routledge, 1979.

Hebdige, Dick. Hiding in the Light: On Images and Things. London: Routledge, 1988.

Jenkins, Philip. Decade of Nightmares: The End of the Sixties and the Making of Eighties America. New York: Oxford UP, 2006.

Katz, Cindy. "Disintegrating Developments: Global Economic Restructuring and The Eroding of Ecologies of Youth." in Tracey Skelton and Gill Valentine (eds.). Cool Places: Geographies of Youth Culture. London: Routledge, 1998. 130-44.

Lyng, Stephen. "Edgework: A Social Psychological Analysis of Voluntary Risk-Taking." American Journal of Sociology 95 (4): 851-886. DOI: 10.1086/229379

Maffesoli, Michel. The Time of the Tribes: The Decline of Individualism in Mass Society. London: Sage, 1996.

Mattson, Kevin. 'What the Heck Are You Up To, Mr. President?': Jimmy Carter, America's "Malaise," and the Speech That Should Have Changed the Country. New York: Bloomsbury, 2009.

Melucci, Alberto. Nomads of the Present: Social Movements and the Individual Needs in Contemporary Society. Philadelphia: Temple UP, 1989.

Patterson, James. Restless Giant: The United States from Watergate to Bush v. Gore. New York: Oxford UP, 2005.

Perlstein, Rick. The Invisible Bridge: The Fall of Nixon and the Rise of Reagan. New York: Simon \& Schuster, 2014.

Sandbrook, Dominic. Mad as Hell: The Crisis of the 1970s and the Rise of the Populist Right. New York: Knopf, 2011.

Schulman, Bruce. The Seventies: The Great Shift in American Culture, Society and Politics. New York: DaCapo, 2001. 
Schulman, Bruce, and Julian Zelizer. Rightward Bound: Making America Conservative in the 1970s. Cambridge: Harvard UP, 2008.

Stark, James. Punk '77: An Inside Look at the San Francisco Rock N' Roll Scene 1977. San Francisco: RE/ Search, 2006.

Wilentz, Sean. The Age of Reagan: A History, 1974-2008. New York: HarperCollins, 2008.

Young, Jock. The Drugtakers: The Social Meaning of Drug Use. London: Paladin, 1971.

Zaretsky, Natasha. No Direction Home: The American Family and the Fear of National Decline, 1968-1980. Chapel Hill: U. of North Carolina P., 2007.

\section{NOTES}

1. Along similar lines, Michel Maffesoli worried (in a book published before his reputation suffered as a result of a number of controversies) that the "festive dimension" of neo-tribal resistance is aimed "less at changing the world than getting used to and tinkering with it" (Maffesoli 51).

2. On the role of emotion in social movement theory, see Goodwin, Jasper and Polletta (2001); and Gould (2009).

3. A great many histories of the United States in the 1970 s build from the premise that the American public, fed up with the excesses of the Sixties, swung to the right politically, most obviously Sandbrook (2011). See also, Schulman (2001); Schulman and Zelizer (2008); Wilentz (2008); Perlstein (2014); Patterson (2005).

4. The Mutants, "New Dark Ages," 45 RPM single, 415 Records 34859, 1980.

5. Numerous songs discussed the betrayal of American draftees and servicemen, including No Alternative's "Johnny Got His Gun," Flipper's "Sacrifice," the Avengers' "The Amerikan in Me," Dead Kennedys' "When Ya Get Drafted," and "We've Got a Bigger Problem Now," the Dils' "Class War" and "National Guard," etc. In addition, the renewal of draft registration garnered widespread coverage in area zines (Eddie K. 1980; "What Will Happen if You do Not Register for the Draft?" 8; "Resist the Draft..." 5; McCarthee 1979; "Register Now, Die Later" 1980). Finally, the prospects of using the neutron bomb as a slum clearing device show up in Dead Kennedys' "Kill the Poor."

6. On tenant eviction battles, see Foley (2015: 66-7); On White Night riot, see Happy Geek (1979), McCarthy (1979); Klein (2015); Coyote (1979). Other bands that played benefit concerts for the May 2st Riot Defense Fund included The Blowdryers, The Contractions, and No Alternative, ("San Francisco Summer 1979" 1979); Reininger and Principle (2016); on mayoral campaign, see "Running for Mayor," Jello Biafra, I Blow Minds for a Living LP, Alternative Tentacles, 1988.

7. As Berlant notes, in a line that could be applied directly to San Francisco punk: "A certain circularity structures an intimate public, therefore: its consumer participants are perceived to be marked by a commonly lived history; its narratives and things are deemed expressive of that history while also shaping its conventions of belonging; and, expressing the sensational, embodied experience of living as a certain kind of being in the world, it promises also to provide a better experience of social belonging - partly through participation in the relevant commodity culture, and partly because of its revelations about how people can live." (Berlant viii).

8. On prefigurative politics, see Breines (1989).

9. Vale 2013; Vale qtd in Stark: 26-27, 28; Penelope Houston, email to Foley, 7 October 2015.

10. Principle quoted in Corbisier (2008: 33).

11. The Mutants' only LP is called Fun Terminal the cover image for which is a photo of the actual Fun Terminal. 
12. I borrow here from Brigit Richard and Heinz Hermann Kruger, who wrote of the 1990s German rave scene's "ability to deliver a political message lies in its power to influence patterns of love and friendship." (Richard and Kruger 1998)

13. In another interview, Schwartz said that punk was all about "makin' noise and bein' crazy and changing the world every day. Without letting corporate culture have its way on us"; Boulware and Tudor (2009: 186-7).

14. For brief history see: "Contents" (1979). On Target video, see: "Target Video" (1979). On the venues, see: "Local Venues" (1979). For brief overview and photos, see: centrefold, and "The Western Front” (1980).

\section{ABSTRACTS}

This essay examines the ways in which politics and leisure were entangled in early San Francisco punk. Although San Francisco is perhaps uniquely associated with the counterculture of the 1960s, the city was, by the late 1970s, also home to a punk scene largely defined by its fierce engagement with political issues. At the same time, punks experienced this scene - which existed at a time of sustained national, state, and local crisis - as deliriously fun. Their idea of fun was vastly different than mainstream ideas of American leisure, but there is no denying that punk, like most subcultures, was experienced at least in part as a leisure activity. I argue that punks acted deliberately to not only intertwine fun and politics, but to make fun and play vehicles for political struggle, if not revolution. At least in this one major American city, punk was equal parts political engagement and diversion, equally confrontational and escapist. More importantly, the leisure and fun elements contributed to the building of a prefigurative community as a micro-model of what punks hoped could be achieved on a larger scale. In that way, fun and politics contributed to a fundamentally utopian vision in a subculture marked not by nihilism - as punk is so often cast - but by possibility.

Cet article examine les modalités des rapports complexes entre politique et loisir aux débuts du mouvement punk à San Francisco. Bien que la ville soit sans doute associée de la manière la plus marquante à la contre-culture des années 60, San Francisco est aussi, à la fin des années 70, le foyer d'une scène punk définie en grande partie par son engagement politique farouche. En même temps, les punks vivent cette expérience - à un moment de crise soutenue au niveau national, régional et local - sur le mode du divertissement exacerbé. Leur idée du divertissement est radicalement différente de celle des idées dominantes en la matière aux États-Unis, mais il est indéniable que le punk, comme la plupart des subcultures, est vécu en partie comme une activité de loisir. Je défends l'hypothèse selon laquelle les punks ont délibérément cherché non seulement à mélanger loisir et politique, mais à faire du loisir et $\mathrm{du}$ jeu un vecteur de lutte politique, sinon révolutionnaire. Au moins à l'échelle de cette ville américaine importante, le punk est tout autant engagement politique et divertissement, antagoniste et récréatif. Surtout, la présence d'éléments de loisir et de divertissement contribue à la formation d'une communauté qui préfigure, sous forme de micro-modèle, ce que les punks espèrent pouvoir réaliser à plus grande échelle. En ce sens, loisir et politique contribuent à une vision fondamentalement utopique d'une subculture marquée non par le nihilisme - comme dans les représentations courantes du punk - mais par les possibles. 
INDEX

Mots-clés: punk, loisirs, divertissement, culture politique, subcultures, San Francisco,

Californie, États-Unis

Keywords: punk, leisure, fun, political culture, subculture, San Francisco, California, United States

\section{AUTHOR}

\section{MICHAEL STEWART FOLEY}

Professor of American Civilization, Université Grenoble Alpes. Michael Stewart Foley is author of Front Porch Politics: The Forgotten Heyday of American Activism in the 1970s and 1980s as well as the 33 $1 / 3$ book on Dead Kennedys' first LP, Fresh Fruit for Rotting Vegetables. He is currently writing a book about the political culture of early San Francisco punk. Contact: Michael.Foley[at]univgrenoble-alpes.fr, foleymichaels[at]gmail.com 